$\begin{array}{ll} & \text { Etnográfica } \\ \text { etnográfica } & \text { Revista do Centro em Rede de Investigação em }\end{array}$

Antropologia

vol. $13(2) \mid 2009$

Vol. $13(2)$

\title{
Ana Bénard da Costa, O Preço da Sombra: Sobrevivência e Reprodução Social entre Famílias de Maputo
}

\section{Ana Luísa Micaelo}

\section{OpenEdition}

\section{Electronic version}

URL: https://journals.openedition.org/etnografica/1176

DOI: 10.4000/etnografica. 1176

ISSN: 2182-2891

\section{Publisher}

Centro em Rede de Investigação em Antropologia

\section{Printed version}

Date of publication: 1 November 2009

Number of pages: 483-484

ISSN: 0873-6561

\section{Electronic reference}

Ana Luísa Micaelo, "Ana Bénard da Costa, O Preço da Sombra: Sobrevivência e Reprodução Social entre Famílias de Maputo", Etnográfica [Online], vol. 13 (2) | 2009, Online since 16 May 2012, connection on 12 February 2022. URL: http://journals.openedition.org/etnografica/1176 ; DOI: https://doi.org/10.4000/ etnografica. 1176

\section{(c) (7) \&}

Etnográfica is licensed under a Creative Commons Attribution-NonCommercial 4.0 International License. 
Ana Bénard da Costa

O PREÇO DA SOMBRA:

SOBREVIVÊNCIA E REPRODUÇÃO SOCIAL ENTRE FAMÍLIAS

DE MAPUTO

Lisboa, Livros Horizonte, 2007, 183 páginas.

A história recente de Moçambique, com destaque para a guerra que opôs a Renamo e a Frelimo e as políticas "modernizantes" subsequentes, provocou uma intensa deslocação das populações, principalmente as que residiam nos meios rurais, em direcção à capital, Maputo. Com o fim da guerra civil, e ao contrário do que se previa, esse êxodo rural não só não se inverteu como não diminuiu. É nos bairros suburbanos da "cidade de cimento" que vive hoje em dia a maioria da população da capital, numa periferia que continua a expandir-se e a crescer também em densidade populacional.

Partindo do pressuposto de que esta situação representou uma desestabilização e transformação para as famílias e os modelos de organização social e económica dos diferentes grupos, a autora propôs-se analisar as estratégias de sobrevivência e reprodução social desenvolvidas pelas famílias "deslocadas de guerra" que residem nos "bairros de caniço" da capital e que são maioritariamente originárias das regiões rurais do Sul do país. A recolha dos dados empíricos foi realizada em três bairros da periferia de
Maputo, Mafalala, Polana Caniço e Hulene B, numa primeira fase, em 1999 e 2001, para a realização da tese de doutoramento em Estudos Africanos Interdisciplinares em Ciências Sociais, e, mais tarde, em 2004 e 2005, no âmbito da sua investigação de pós-doutoramento.

Assim, Ana Bénard da Costa argumenta que as estratégias de sobrevivência destas famílias passam pela dispersão económica e geográfica dos seus membros, ou seja, a mobilidade territorial, tanto dos meios rurais para os urbanos como dentro da própria cidade de Maputo e entre os vários bairros da sua periferia, assume-se como parte fundamental das estratégias de sobrevivência e reprodução social destas famílias. Note-se que, para a grande maioria dos indivíduos e famílias, a vinda para a cidade não implicou uma ruptura com o espaço rural ou com a família que aí continuou a residir, possibilitando por isso que a circulação de pessoas entre o campo e a cidade seja constante e se processe de diferentes formas - seja a deslocação temporária das mulheres para trabalhar na machamba, cujos produtos servem o consumo doméstico e a venda nos mercados informais da capital, sejam as visitas regulares das crianças aos seus parentes na terra de origem do pai, ou ainda a presença de jovens rapazes em casa de familiares que residem em Maputo.

No que concerne às estratégias económicas de sobrevivência e reprodução social destas famílias, a autora adverte que não 
é tarefa fácil aferi-las (p. 123). Devido ao crescimento do sector informal da economia da cidade e às condições de inconstância e imprevisibilidade do contexto, as actividades dos diferentes membros da família, homens e mulheres, dispersam-se pelos vários sectores, formal e informal, em regime de pluriactividade e complementaridade.

Do mesmo modo, a coexistência de diferentes sistemas matrimoniais, relações conjugais e de género, relacionadas com a multiplicidade de quadros de referência, normas e modelos culturais em presença, permite o desenvolvimento de estratégias de reprodução social adaptadas a um contexto social e económico que exige uma grande flexibilidade e versatilidade de práticas. Assim, alguns dos referentes mais importantes da identidade familiar entre os habitantes da periferia de Maputo são o culto dos antepassados e as relações entre vivos e mortos, a relação com a "terra de origem” e ainda a atribuição de nomes próprios, símbolos de identificação familiar habilmente manipulados e adaptados em função de interesses vários e das estratégias accionadas.

Segundo a antropóloga, existe uma articulação fundamental entre a dimensão religiosa e o sistema de parentesco tsonga, cuja análise simultânea apresenta como um dos meios privilegiados para compreender as estratégias de sobrevivência e reprodução social das famílias, assim como os processos identitários e simbólicos que estas implicam (p. 61). Há que ter em conta que, tanto em termos de práticas familiares como de práticas terapêuticas e adesão às organizações religiosas, os vários referentes disponíveis não são mutuamente exclusivos, mas articulados permanentemente. Por seu turno, as igrejas funcionam como importantes redes de solidariedade, o que influi decisivamente nas estratégias de sobrevivência das famílias. Elas dão um apoio muito concreto aos membros das famílias, sobretudo às mulheres, ajudando-as a educar as crianças e jovens e a gerir os conflitos que surgem entre os diferentes membros da família, sobretudo conjugais (ainda que possam também ser uma fonte de conflitos, através de acusações de feitiçaria que recaem geralmente sobre os parentes mais próximos ou mesmo das tentativas de conversão).

Uma vez que se trata da adaptação da tese de doutoramento a livro, é compreensível a exclusão do capítulo de problematização teórica fundamental à dissertação (defendida em 2003, no ISCTE). No entanto, talvez a estrutura do texto pudesse ter sido revista. Ao desenvolver mais a contextualização da problemática, eventualmente através da introdução das histórias de família mais cedo no livro, a autora permitiria uma melhor compreensão das estratégias em causa e, no fundo, da verosimilhança destas vivências, sem enfatizar tanto a procura da coerência ou coesão das práticas, valores e formas de vida destas pessoas. Há ainda que acentuar a relevância do trabalho para a discussão sobre a forma como a mobilidade se inscreve nas práticas familiares contemporâneas, mesmo que o envolvimento da autora com o contexto moçambicano, que não começa nem acaba neste livro, possa extravasar este enfoque propriamente temático. Assim, através da análise das histórias de família de algumas das pessoas que vivem nestes bairros em expansão, O Preço da Sombra permite-nos não só relacionar as mudanças que foram ocorrendo nestas famílias com o contexto de onde elas são originárias e com o qual se relacionam frequentemente, como também problematizar as dinâmicas de poder - económicas, étnicas/raciais, religiosas, de género, etc. - que acontecem nos meandros das grandes cidades africanas contemporâneas como Maputo.

\section{Ana Luísa Micaelo}

Doutoranda no ICS-UL, bolseira FCT 